\title{
Multiple traits selection in bread wheat under drought stress and normal irrigation
}

\author{
Rasha E. Mahdy,* \\ Agronomy Department, Faculty of Agriculture, Assuit University, 71515, Egypt
}

\begin{abstract}
The genetic materials were $\mathrm{F}_{2}, \mathrm{~F}_{3}, \mathrm{~F}_{4}$ and $\mathrm{F}_{5}$ generations of the cross "Giza164/Sids4" of bread wheat. The experiments were conducted under drought stress and normal irrigation. Three cycles of single trait selection for grain yield/plant (GY/P) and five models of desired gain selection index (combinations from seven traits) were achieved in both environments separately. After the third cycle of selection, the selected families for the six types of selection under drought stress, and the selected families under normal irrigation were evaluated under both environments. The GCV in GY/P decreased from the $F_{2}$ to the $F_{5}$. The remained variability in GY/P for the five selection indices was higher after the three cycles of selection than the single trait selection for GY/P. Heritability estimates as calculated from regression of $\mathrm{F}_{5} / \mathrm{F}_{4}$ generations for the traits under selection pressure were higher under drought stress than under normal irrigation except few cases. The observed gain increased from index $x_{1}$ to index 5 , and all indices were better in improving GY/ $P$ than direct selection for GY/P. It could be concluded that selection index was better in improving grain yield than single trait selection for GY/P. Furthermore, selection under drought stress (antagonistic selection) in these materials was better than selection under normal irrigation (synergistic selection) in improving GY/P either selection evaluated under drought stress or under normal irrigation. Selection index 5 which involved GY/P, 100GW and NG/S was the best index in improving GY/P.
\end{abstract}

Keywords: Triticum aestivum, Drought stress, Selection index, Realized heritability, Observed genetic gain.

\section{Introduction}

Egypt is the main country importing wheat worldwide. The production of wheat in 2017 was 8.8 million metric tons, and the estimated import of wheat in 2018/19 (July/June) is 12.5 million metric tons (FAO 2017). Developing new high yielding cultivars and expand the cultivated area in new reclaimed soils and the northern coast could lessen the heavy burden of wheat import.

\footnotetext{
*Corresponding author: Rasha E. Mahdy

rasha.mahdy@aun.edu.eg

Received: August 8, 2020;

Accepted: September 3, 2020;

Published: September 8, 2020.
}

Pedigree selection proved to be an efficient procedure in improving grain yield

(GY). Early generation selection is desirable by many researchers (Bhatt 1980, Whan et al 1981, 1982, Sip and Skorpik 1985 and Nass 1987) because a genotype possessing all the favorable genes in either the homozygous or heterozygous condition occurs often in the $F_{2}$ generation, and its frequency decline in subsequent generations. Otherwise, many papers noted a very low efficiency of selection started in the $F_{2}$ because of high level of heterozygosity and low heritability of the complex traits. Borghi et al 
(1998) found that GY of spaced plants in the $F_{2}$ and $\mathrm{F}_{3}$ generations was weakly correlated with that of the $\mathrm{F}_{4}$ and successive generations grown at normal seed density. Ismail et al (1996) noted that one cycle of selection for GY started in the $\mathrm{F}_{5}$ was better than three cycles started in the $\mathrm{F}_{3}$ generation. Mahdy (2017) found that the observed genetic gain of the one cycle of selection from the $\mathrm{F}_{4}$ generation under both drought stress and normal irrigation environments was mostly better than three cycles started from $\mathrm{F}_{2}$ generation. Therefore, most of plant breeders and research centers delay selection for yield to the $\mathrm{F}_{5}$ generation after the plants reached acceptable level of homozygosity. Ismail (1995) increased GY/P by 4.86 and $6.41 \%$ of the better parent in two populations after two cycles of selection for GY per se. Hamam (2008) noted that two cycles of selection for GY/P increased grain yield/plant by 14.14 and $15.97 \%$ of the better parent in two populations. After two cycles of selection, Zakaria et al (2008) achieved observed genetic gain in GY/P of 7.62 and 7.54 $\%$ of the better parent under normal and late plantings, respectively. Single trait selection for GY in bread wheat was effective (Mahdy 1988, Pawar et al 1990, Ismail 1995 and 2001, Ismail et al 1996, Mahdy et al 1996 and 2012, Ahmed 2006, El-Karamity et al 2007, Khan et al 2007, Ali 2011 and Mahdy 2017). Talebi et al (2009) found that gain from indirect selection under moisture stress would improve yield in moisture stress better than selection from non-moisture stress environment. Ali (2011), Mahdy (2012), Mahdy et al (2012), Mahdy et al (2015) and Mahdy (2017) found that the observed genetic gain in grain yield under drought stress was better than under normal irrigation. In some cases, the genetic gains for single trait selection could generate adverse effects on the correlated traits (Hanson 1991and Collins et al 1997).

Index selection is one of the best methods for the genetic improvement of traits simultaneously in crop plants. A theory of discriminate function which introduced by Smith (1936) in plants and Hazel (1943) in animals is now known as SmithHazel index, base index (Williams 1962) and desired gain index (Pesek and Baker1969) proved to be the best methods of selection. Gebre-Mariam' and Larter (1996) indicated that Smith-Hazel index proved to be the best to improve grain yield and kernel weight but resulted in substantial decrease in grain protein level of four spring wheat crosses. Mahdy et al (1996) showed that Smith-Hazel, desired gain index of three traits (No. of spikelet's /spike,1000-kernel weight and GY/P) and single trait selection for GY/P gave observed genetic gain in GY/P of 13.21, 16.04, and $12.67 \%$ of the better parent, respectively after three cycles of selection. Cargnin et al (2007) found that the desired gain index gave the highest genetic gain compared to Smith-Hazel and Williams indices. Ferdous et al (2010) through discriminate functions using eight traits indicated that the highest relative efficiency was observed with the selection index based on three characters; plant height, grains per spike and grain yield per plant. Ghaed-Rahimi et al (2017) estimated the efficiency of selection $(\Delta H)$ under drought stress at heading and well-irrigated conditions. It was 19.95 and 16.5 in the first and 11.15 and 11.06 in the second year for desired gain index and was more efficient than Smith-Hazel index $(\Delta H=$ 9.58 and 8.97 in the first and 9.74 and 8.59 in the second year) under drought stress at heading and well-irrigated conditions, respectively. Fellahi et al (2018) found that the base index of Williams ranked the first followed by the Smith Hazel index for simultaneous selection of superior lines for yield and its components. Jinks and Connolly (1973 and 1975) studied the relationship between selection environment and environmental sensitivity (stability) in Schizophyllum commune. They concluded that the sensitivity of selection to environment was reduced if selection and environment effects were in opposite direction. Falconer (1990) suggested that antagonistic 
selection was significantly better than synergistic selection for changing the mean, but there is no theoretical justification for this expectation.

The objective of this study was to measure and compare observed genetic gains in grain yield and correlated traits in three cycles of selection started in the $\mathrm{F}_{2}$ generation of spring wheat cross (Giza $164 \times$ Sids 4 ), based on single-trait selection for grain yield and five models of desired gain selection index (Pesek and Baker 1969) from seven traits under drought stress and normal irrigation environments.

Table 1. Planting date and experimental design

\section{Materials and methods}

The genetic materials were $\mathrm{F}_{2}, \mathrm{~F}_{3}, \mathrm{~F}_{4}$ and $\mathrm{F}_{5}$ generations of the cross "Giza164/Sids4" of bread wheat (Triticum aestivum L.). The experiments were conducted under irrigation and drought stress environments during the four seasons of 2012/13 to 2016/17 at Faculty of Agriculture Experimental farm, Assiut University, Egypt (latitude $=27.178^{\circ}$, Longitude $=31.185^{\circ}$ ). The soil texture is clay.

\begin{tabular}{llcll}
\hline Season & Date & Generation & Experimental design \\
& & & Irrigation & Drought stress \\
\hline $2012 / 13$ & $5 / 12 / 2012$ & $\mathrm{~F}_{2}$ & Non-replicated plots & Non-replicated plots \\
$2014 / 15$ & $25 / 12 / 2014$ & $\mathrm{~F}_{3}$ & RCBD with 3-Reps & RCBD with 3-Reps \\
$2015 / 16$ & $17 / 12 / 2015$ & $\mathrm{~F}_{4}$ & $"$ & $"$ \\
$2016 / 17$ & $5 / 12 / 2016$ & $\mathrm{~F}_{5}$ & $"$ & $"$ \\
\hline
\end{tabular}

\section{Irrigation}

The experiments under normal irrigation in the four seasons, received planting irrigation and four irrigations throughout the growing season. However, the experiments under drought stress received planting irrigation..

\section{Fertilization}

In all experiments, super phosphate $\left(\mathrm{P}_{2} \mathrm{O}_{5}\right.$, $15.5 \%$ ) was added during land preparation at a rate of $150 \mathrm{~kg} / \mathrm{Fed}\left(\right.$ Feddan $\left.=4200 \mathrm{~m}^{2}\right)$. Nitrogen fertilization in the form of ammonium nitrate $(33.5 \% \mathrm{~N})$ was added at a rate of $80 \mathrm{~kg} \mathrm{~N} / \mathrm{Fed}$ in one dose before the first irrigation.

Three cycles of single trait selection for grain yield/plant (GY/P) and desired gain selection index were performed in both environments separately. In season 2012/13, the $F_{2}$ seeds were sown under normal irrigation and drought stress environments in non-replicated plots, in rows 3 $\mathrm{m}$ long, $30 \mathrm{~cm}$ apart and $15 \mathrm{~cm}$ between seed within a row. The parents were grown in separate plots. The data were recorded on 440 guarded plants in both environments. The recorded data in all generations were days to heading (DH), plant height; cm (PH), spike length; cm (SL), number of spikes/plant (NS/P), grain yield/plant; $g$ $(\mathrm{GY} / \mathrm{P})$, number of grains/spike (NG/S), grain weight of main spike (WMS) and 100-grain weight; $g(100-\mathrm{GW})$.

After harvest, the single plants (440) were ranked for GY/P and for 5 models of the modified "desired genetic gain" index (Pesek and Baker 1969 and 1970). The highest 40 plants in grain yield and the five models of index selection were saved from both environments for the next generation. The traits involved in selection index (Ind) were as follows: 
Ind $_{1}$ involved DH, SL, NS/P, WMS, NG/S, 100GW, GY/P

Ind $_{2}$ involved DH, NG/S, 100-GW, GY/P

$\mathrm{Ind}_{3}$ involved DH, SL, NG/S, 100-GW, GY/P

$\mathrm{Ind}_{4}$ involved SL, NG/S, 100-GW, GY/P

Ind $_{5}$ involved NG/S, 100-GW, GY/P

In season $2014 / 15\left(\mathrm{~F}_{3}\right.$-generation), grains of the 40 selected plants for GY/P, and the 40 selected plants for each of the five selection index models along with the parents were grown in rows under normal irrigation and drought stress environments in a RCBD with three replications. The plot size was single row, $3 \mathrm{~m}$ long, $30 \mathrm{~cm}$ apart and $10 \mathrm{~cm}$ between grains within a row. Data were recorded on 20 guarded plants from each family. At the end of the season, the best 20 plants in GY/P and from each index were saved from the best 20 families from each experiment for the next season. The same procedure was done in season 2015/16 ( $\mathrm{F}_{4}$-generation) and 10 selected plants were saved for each selection procedure for evaluation in the $\mathrm{F}_{5}$ - generation (season 2016/17). The selected plants under an environment were evaluated in the $\mathrm{F}_{5}$-generation under both environments.

\section{Statistical analysis}

Data were subjected to statistical and separation mean analyses on plot mean basis according to Steel and Torrie (1980). Heritability in broad sense " $H$ " was estimated as the ratio of genotypic $\left(\sigma^{2} \mathrm{~g}\right)$ to phenotypic $\left(\sigma^{2} \mathrm{p}\right)$ variance (Walker 1960). Realized heritability was calculated as parent-offspring regression as outlined by Smith and Kinman (1965). The phenotypic (PCV\%) and genotypic (GCV\%) coefficients of variability were calculated as outlined by Burton (1952). Estimation of phenotypic covariance between pairs of traits of single plants in the $F_{2}$ generation depended on the mathematical fact:

$\mathrm{IFC}=\mathrm{A}+\mathrm{B}$ Then $\sigma_{\mathrm{C}}^{2}=\sigma^{2}{ }_{\mathrm{A}}+\sigma_{\mathrm{B}}^{2}+2 \mathrm{COV}$ $\mathrm{AB}$
Estimatates of genotypic variances and covariances in the next seasons were calculated from expected mean squares and expected mean cross products according to Walker (1960). Pesek and Baker (1969 and 1970) modification of the theory of index selection was calculated each cycle for each selection index model. The calculation of index coefficients were done according to the following matrix formulation: $b$ $=\mathrm{G}-1 \mathrm{~h} \times \mathrm{p} / \mathrm{z}$ where $\mathrm{b}=$ the vector of index coefficients, G-1 = the inverse of the genotypic variance and covariance matrix, $\mathrm{h}=$ the vector of desired genetic gains ( $h$ was assigned as $10 \%$ increase of each trait in the index except for $\mathrm{DH}$ it was $10 \%$ decrease from the population mean), $\mathrm{p} / \mathrm{z}=$ the reciprocal if selection differential in standard units. Since $p / z$ is constant for any experiment, an equivalent solution can be obtained from: $b=\mathrm{G}-1 \mathrm{~h}$. The phenotypic value of a family (I) was estimated as I = bi xi (Smith 1936) and (Hazel 1943) where bi is the weighting factor and $\mathrm{xi}$ is the phenotypic value for the ith trait. The observed genetic gain from selection (OG\%) was calculated as the deviation percentage from the better parent.

\section{Results and discussion}

\section{Description of the base population; F2 generation}

Brief description of the parents and $\mathrm{F}_{2}$-generation under normal irrigation and drought stress environments is presented in Table 1 (the $F_{2}$ description was discussed in detail in the previous paper "Mahdy and Elfarash 2018). Mean grain yield/plant (GY/P) of the parents Sids4 and Giza164 was 20.11 and $30.77 \mathrm{~g}$ under normal irrigation, and 18.21 and 25.81 under drought stress with reduction of 13.64 and $25.86 \%$, respectively. Mean GY/P of the $F_{2}$ was 22.56 and $15.79 \mathrm{~g}$ under normal irrigation and drought stress, respectively, with reduction of $42.88 \%$. The $\mathrm{F}_{2}$ mean lied between the two parents with partial dominance towards the low 
yielding parent. Phenotypic (PCV) and genotypic (GCV) coefficients of variability were high in the $\mathrm{F}_{2}$ and accounted for 48.31 and $28.59 \%$ under normal irrigation, and 76.0 and $45.81 \%$ under drought stress, respectively, indicating enough variability for selection for GY/P. Such wide variability with broad sense heritability of 35.01 and $36.34 \%$ resulted in predicted genetic advance Table 2. Means of the studied traits in the $\mathrm{F}_{2}$, parents, reduction $\%$, heritability in broad sense $(\mathrm{H})$ and
genetic advance $(\mathrm{GA})$ under selection of $10 \%$ superior plants. genetic advance (GA) under selection of $10 \%$ superior plants.

\begin{tabular}{|c|c|c|c|c|c|c|c|c|}
\hline \multirow{3}{*}{ Item } & \multicolumn{8}{|c|}{ Normal irrigation } \\
\hline & $\mathrm{DH}$ & $\mathrm{PH}(\mathrm{cm})$ & $\mathrm{SL}(\mathrm{cm})$ & $\mathrm{NS} / \mathrm{P}$ & GY/P (g) & MSW (g) & 100GW (g) & $\mathrm{NG} / \mathrm{S}$ \\
\hline & \multicolumn{8}{|c|}{$\mathrm{F}_{2}$} \\
\hline Mean \pm SE & $\begin{array}{c}81.92 \pm \\
0.18\end{array}$ & $\begin{array}{l}89.030 \\
\pm 0.32 \\
\end{array}$ & $\begin{array}{r}12.57 \\
\pm 0.08 \\
\end{array}$ & $\begin{array}{c}9.57 \\
\pm 0.20 \\
\end{array}$ & $\begin{array}{r}22.56 \\
\pm 0.52 \\
\end{array}$ & $\begin{array}{c}3.06 \\
\pm 0.04 \\
\end{array}$ & $\begin{array}{c}5.21 \\
\pm 0.026 \\
\end{array}$ & $\begin{array}{r}58.54 \\
\pm 0.77 \\
\end{array}$ \\
\hline $\mathrm{PCV} \%$ & 6.14 & 6.71 & 6.59 & 25.11 & 48.31 & 18.57 & 7.44 & 22.81 \\
\hline GCV\% & 2.10 & 5.30 & 1.64 & 4.08 & 28.59 & 17.92 & 0.44 & 13.19 \\
\hline $\mathrm{H} \%$ & 21.15 & 41.67 & 61.39 & 66.95 & 35.01 & 36.80 & 42.81 & 22.79 \\
\hline GA & 1.39 & 4.92 & 1.84 & 4.80 & 6.70 & 0.58 & 0.41 & 6.46 \\
\hline GA/Mean\% & 1.70 & 5.51 & 14.65 & 50.18 & 38.61 & 19.06 & 7.85 & 11.05 \\
\hline \multicolumn{9}{|c|}{ Sids 4} \\
\hline Mean \pm SE & $\begin{array}{c}71 \\
\pm 0.95 \\
\end{array}$ & $\begin{array}{r}79.09 \\
\pm 1.16 \\
\end{array}$ & $\begin{array}{l}14.67 \\
\pm 0.21 \\
\end{array}$ & $\begin{array}{c}5.57 \\
\pm 0.31 \\
\end{array}$ & $\begin{array}{l}20.11 \\
\pm 1.71 \\
\end{array}$ & $\begin{array}{l}5.05 \\
\pm 0.2 \\
\end{array}$ & $\begin{array}{c}5.67 \\
\pm 0.09 \\
\end{array}$ & $\begin{array}{c}63.6 \\
\pm 4.07 \\
\end{array}$ \\
\hline & \multicolumn{8}{|c|}{ G 164} \\
\hline Mean \pm SE & $\begin{array}{c}88.08 \pm \\
0.36\end{array}$ & $\begin{array}{l}92.76 \\
\pm 0.99\end{array}$ & $\begin{array}{l}10.64 \\
\pm 0.23\end{array}$ & $\begin{array}{c}11.6 \\
\pm 0.60 \\
\end{array}$ & $\begin{array}{l}30.77 \\
\pm 1.92\end{array}$ & $\begin{array}{c}3.12 \\
\pm 0.04\end{array}$ & $\begin{array}{c}5.03 \\
\pm 0.08\end{array}$ & $\begin{array}{l}66.68 \\
\pm 0.77\end{array}$ \\
\hline \multicolumn{9}{|c|}{ Drought stress } \\
\hline \multicolumn{9}{|c|}{$\mathrm{F}_{2}$} \\
\hline Mean \pm SE & $\begin{array}{l}77.74 \\
\pm 0.2\end{array}$ & $\begin{array}{r}85.02 \\
\pm 0.33\end{array}$ & $\begin{array}{l}11.92 \\
\pm 0.1\end{array}$ & $\begin{array}{r}7.18 \\
\pm 0.2\end{array}$ & $\begin{array}{c}15.79 \\
\pm 0.6\end{array}$ & $\begin{array}{c}2.91 \pm \\
0.05\end{array}$ & $\begin{array}{c}4.93 \pm \\
0.05\end{array}$ & $\begin{array}{c}53.76 \pm \\
0.75\end{array}$ \\
\hline Reduction $\%$ & 5.10 & 4.09 & 5.17 & 24.97 & 42.88 & 4.9 & 5.37 & 8.01 \\
\hline PCV\% & 5.15 & 7.76 & 16.78 & 55.71 & 76.00 & 34.36 & 20.28 & 27.90 \\
\hline GCV\% & 4.08 & 4.25 & 12.93 & 41.45 & 45.81 & 23.66 & 17.57 & 4.99 \\
\hline $\mathrm{H} \%$ & 62.84 & 29.98 & 59.38 & 55.36 & 36.34 & 27.00 & 75.00 & 27.35 \\
\hline GA & 4.41 & 3.47 & 2.08 & 3.89 & 7.65 & 0.47 & 1.32 & 7.20 \\
\hline GA/Mean & 5.67 & 4.08 & 17.48 & 54.13 & 48.46 & 16.28 & 26.70 & 13.39 \\
\hline \multicolumn{9}{|c|}{ Sids 4} \\
\hline Mean \pm SE & $\begin{array}{r}69.00 \\
\pm 0.6 \\
\end{array}$ & $\begin{array}{l}70.11 \\
\pm 1.2 \\
\end{array}$ & $\begin{array}{c}14.17 \\
\pm 0.20 \\
\end{array}$ & $\begin{array}{c}4.81 \\
\pm 0.35\end{array}$ & $\begin{array}{r}18.21 \\
\pm 1.71 \\
\end{array}$ & $\begin{array}{c}4.55 \\
\pm 0.22 \\
\end{array}$ & $\begin{array}{c}5.1 \\
\pm 0.10 \\
\end{array}$ & $\begin{array}{c}75.0 \\
\pm 3.17 \\
\end{array}$ \\
\hline Reduction $\%$ & 2.82 & 11.35 & 3.41 & 13.64 & 9.45 & 9.9 & 11.18 & 12.38 \\
\hline \multicolumn{9}{|c|}{ G164 } \\
\hline Mean \pm SE & $\begin{array}{c}85.18 \pm \\
0.34\end{array}$ & $\begin{array}{r}90.86 \\
\pm 01.0\end{array}$ & $\begin{array}{c}10.4 \\
\pm 0.30\end{array}$ & $\begin{array}{c}8.6 \\
+0.67 \\
\end{array}$ & $\begin{array}{l}25.81 \\
\pm 2.1\end{array}$ & $\begin{array}{r}2.89 \\
\pm 0.1 \\
\end{array}$ & $\begin{array}{c}4.5 \\
\pm 0.10 \\
\end{array}$ & $\begin{array}{l}55.67 \\
\pm 0.8\end{array}$ \\
\hline Reduction $\%$ & 3.29 & 2.05 & 2.26 & 25.86 & 16.12 & 7.37 & 10.54 & 16.51 \\
\hline
\end{tabular}

$\mathrm{SE}=$ standard error, Reduction $\%=($ mean under normal-mean under stress $) /$ mean under normal $\times 100$.

Broad sense heritability varied greatly under both environments. It ranged from $21.15 \%$ for $\mathrm{DH}$ to $66.95 \%$ for NS/P under normal irrigation and from $29.98 \%$ for plant height to $75.0 \%$ for 100 GW under drought stress. In consequence, the predicted genetic gain under selection of 10 for GY/P in percentage of the mean of 38.61 and $48.46 \%$ under normal irrigation and drought stress environments; respectively. Our results are in general agreement with those reported by Mahdy (2012) and Mahdy et al (2012 and 2015). The reduction in the other traits, ranged from $4.09 \%$ for plant height to $24.97 \%$ for NS/P. Normal irrigation 
short spike length $(10-11 \mathrm{~cm})$, large NS/P, high GY/P and medium $100 \mathrm{GW}$ (4.5 - $5 \mathrm{~g}$ ) (Table2).

\section{Evaluation under drought stress}

After the third cycle of selection, the selected families for the six types of selection under drought stress (drought stress group), and the selected families under normal irrigation (normal irrigation group) were evaluated under both environments. The results (Table 2) showed that the GCV in GY/P decreased from 45.81 and $28.59 \%$ in the $F_{2}$ to 19.16 and $11.96 \%$ in the $F_{5-}$ generation for drought and normal irrigation groups, respectively. The remained variability in GY/P for the five selection indices was higher after the three cycles of selection than the single trait selection for GY/P.

Furthermore, except for index 1 the GCV in GY/P of the drought group was higher than that of the normal irrigation group. The remained GCV could be considered enough for the further cycles of selection. NS/P and NG/S showed enough genetic variability for further evaluation under normal irrigation. GY/P of the drought group was higher than that of the normal irrigation group. The remained GCV could be considered enough for further cycles of selection. Besides, NS/P and NG/S showed enough genetic variability for further cycles of selection, and the GCV was higher in the drought stress group for the selection methods except for single trait selection for GY/P and Index 3 . The variability in the other traits showed no trend.

\section{Evaluation under normal irrigation}

The results show that the GCV in GY/P decreased from 45.81 and $28.59 \%$ in the $\mathrm{F}_{2}$ (Table 1) to 22.25 and $18.87 \%$ in the $\mathrm{F}_{5}$ generation (Table 3) for drought stress and normal irrigation groups, respectively, when selection was for GY/P per se. The remained GCV in GY/P was higher in stress group than normal irrigation group for single trait selection, Index $_{1}$ and Index $_{3}$, respectively. The genetic variability in NS/P was higher in drought stress than normal irrigation group except for Index 3 .
The remained genetic variability in the other traits showed no trend.

Except for DH the remained genetic variability could be considered enough for further cycles of selection. The retained genetic variability varied greatly according to method of selection and variation in the base population. Ismail (1995) showed that the GCV\% decreased in two populations from 144.6 and 111.07 in the $F_{3}$ to 19.24 and $18.41 \%$ after two cycles of selection for GY/P. In another work Ismail et al (1996) noted GCV\% of 4.97 in GY/P in cycle 3. Mahdy et al (1996) indicated to the decrease of GCV in GY/P from $38.69 \%$ in $F_{3}$ base population to $5.28 \%$ after three cycles of selection. Mahdy et al (2012) after three cycles of selection for GY/P found GCV of $14.93 \%$ under normal irrigation and $16.64 \%$ under drought stress conditions.

\section{Narrow sense heritability}

Heritability estimates as calculated from regression of $F_{5} / F_{4}$ generations (Table 4 ) for the traits under selection pressure were higher under drought stress than under normal irrigation except for five out of twenty-three cases in index selection and direct selection for GY/P. Generally, the regression coefficients of $\mathrm{F}_{5} / \mathrm{F}_{4}$ were low for such quantitative traits, and it was affected by genotype $\mathrm{x}$ environment interaction, in which the parental families $\left(\mathrm{F}_{4}\right)$ was evaluated in a season and their offspring $\left(\mathrm{F}_{5}\right)$ in another year. Borghi et al (1998) reported realized heritability for grain yield of 7 to $70 \%$ in the $\mathrm{F}_{5}$ of nine populations subjected to direct selection for grain yield.

Mahdy et al (2012) after three cycles of direct selection for grain yield noted realized heritability of $78.46 \%$ under normal irrigation and $37.88 \%$ under drought stress. Fellahi et al (2018) noted narrow sense heritability of $10.13 \%$ for grain yield after index selection (desired grain index).

\section{Observed and correlated genetic gain \\ Cycle1 selection (F3-generation)}


Single trait selection for GY/P under stress showed significant direct observed genetic gain (OG) of $7.97 \%$ for cycle1 compared to $8.1,10.2$, $10.30,12.10$ and $16.30 \%$ of the better parent for inde $_{1}, 2,3,4$ and 5: respectively (Table 5 and Fig.1). All methods of index selection were better than single trait selection for GY/P, and index 5 was the best. Selection for GY/P accompanied with significant decrease in SL, WMS and 100GW and increase in days to heading. Such decreases for these correlated traits were mostly less in selection index models. Index $x_{1,2}$ and 3 which involved DH showed insignificant differences in DH with the earlier parent "Sids $4 "$.

Table 3. Phenotypic (PCV) and genotypic (GCV) coefficients of variability in cycle 3 in the $\mathrm{F}_{5}$ generation under drought stress evaluation.

\begin{tabular}{|c|c|c|c|c|c|c|c|c|c|c|}
\hline $\begin{array}{l}\text { Selection } \\
\quad \text { for }\end{array}$ & $\begin{array}{l}\text { Selection } \\
\text { site }\end{array}$ & Item & $\mathrm{DH}$ & $\begin{array}{c}\mathrm{PH} \\
(\mathrm{cm})\end{array}$ & $\begin{array}{l}\mathrm{SL} \\
(\mathrm{cm})\end{array}$ & $\mathrm{NS} / \mathrm{P}$ & $\begin{array}{c}\text { GY/P } \\
(\mathrm{g})\end{array}$ & $\begin{array}{c}\text { MSW } \\
(\mathrm{g})\end{array}$ & $\begin{array}{c}100 \mathrm{GW} \\
(\mathrm{g})\end{array}$ & NG/S \\
\hline \multirow{4}{*}{ GY/P } & \multirow[t]{2}{*}{$S$} & GCV\% & 3.15 & 6.72 & 6.52 & 24.81 & 19.16 & NS & 12.10 & 13.60 \\
\hline & & PCV\% & 3.33 & 7.03 & 8.53 & 25.06 & 20.15 & NS & 12.20 & 15.25 \\
\hline & \multirow[t]{2}{*}{$\mathrm{N}$} & GCV\% & 1.99 & 9.47 & 6.44 & 26.57 & 11.96 & 14.11 & 10.56 & 23.43 \\
\hline & & PCV\% & 2.07 & 9.52 & 7.24 & 26.61 & 12.19 & 14.41 & 10.63 & 23.63 \\
\hline \multirow{4}{*}{ Index 1} & \multirow[t]{2}{*}{$S$} & GCV\% & 3.31 & 12.50 & 8.71 & 34.42 & 28.65 & 28.34 & NS & 23.42 \\
\hline & & PCV\% & 3.35 & 12.54 & 9.28 & 34.95 & 31.72 & 28.45 & NS & 24.70 \\
\hline & \multirow[t]{2}{*}{$\mathrm{N}$} & GCV\% & 4.48 & 12.10 & 8.35 & 18.99 & 34.42 & 14.74 & 3.66 & 13.05 \\
\hline & & PCV\% & 4.53 & 12.13 & 8.70 & 19.02 & 34.95 & 15.00 & 4.01 & 13.38 \\
\hline \multirow{4}{*}{ Index 2} & \multirow[t]{2}{*}{$\mathrm{S}$} & GCV\% & 2.90 & 7.95 & 8.38 & 15.17 & 28.80 & 24.20 & 6.66 & 21.64 \\
\hline & & PCV\% & 2.99 & 8.08 & 8.88 & 15.19 & 29.56 & 24.32 & 7.00 & 21.78 \\
\hline & \multirow[t]{2}{*}{$\mathrm{N}$} & GCV\% & 3.13 & 12.35 & 12.71 & 14.38 & 17.79 & 15.90 & 6.29 & 17.82 \\
\hline & & PCV\% & 3.20 & 12.44 & 12.82 & 14.95 & 19.91 & 16.01 & 6.52 & 17.97 \\
\hline \multirow{4}{*}{ Index 3} & \multirow[t]{2}{*}{ S } & GCV\% & 3.85 & 6.47 & 9.91 & 14.47 & 31.11 & 23.76 & 8.12 & 20.66 \\
\hline & & PCV\% & 3.90 & 6.80 & 10.39 & 14.49 & 32.88 & 24.13 & 8.38 & 21.29 \\
\hline & \multirow[t]{2}{*}{$\mathrm{N}$} & GCV\% & 4.39 & 7.94 & 11.09 & 15.06 & 27.71 & 30.10 & 8.34 & 22.42 \\
\hline & & PCV\% & 4.46 & 8.18 & 11.40 & 15.11 & 28.42 & 30.32 & 8.40 & 22.58 \\
\hline \multirow{4}{*}{ Index 4} & \multirow[t]{2}{*}{ S } & GCV\% & 2.56 & 6.45 & 9.63 & 21.14 & 27.05 & 26.78 & 6.72 & 20.33 \\
\hline & & PCV\% & 2.64 & 6.64 & 10.03 & 21.15 & 27.57 & 27.01 & 6.92 & 20.62 \\
\hline & \multirow[t]{2}{*}{$\mathrm{N}$} & GCV\% & 2.62 & 5.72 & 14.98 & 18.26 & 17.85 & 30.64 & 42.95 & 25.90 \\
\hline & & PCV\% & 2.72 & 6.36 & 15.54 & 18.79 & 21.30 & 30.70 & 51.25 & 26.00 \\
\hline \multirow{4}{*}{ Index 5} & \multirow[t]{2}{*}{$\mathrm{S}$} & GCV\% & 3.67 & 9.46 & 11.45 & 20.47 & 33.14 & 14.82 & 11.76 & 16.27 \\
\hline & & PCV\% & 3.73 & 9.55 & 11.86 & 20.54 & 34.69 & 15.44 & 12.04 & 16.93 \\
\hline & \multirow[t]{2}{*}{$\mathrm{N}$} & GCV\% & 2.51 & 11.29 & 11.56 & 12.85 & 30.27 & 15.43 & 7.03 & 14.86 \\
\hline & & PCV\% & 2.63 & 11.54 & 12.21 & 14.08 & 32.25 & 15.80 & 7.13 & 15.04 \\
\hline
\end{tabular}

NS = insignificant genotypes mean squares, $\mathrm{S}=$ drought stress, $\mathrm{N}=$ normal irrigation

Improving GY/P of all methods of selection than the better parent "G164", caused the other correlated traits to be in the mid-way between the two parents.

Selection under normal irrigation showed better OG in GY/P for all indices. However direct selection for GY/P was negative and insignificant. Selection under normal irrigation reflects the same trend of selection under stress with remarkable increase in traits mean.

\section{Cycle2 selection (F4- generation)}

Cycle 2 selection reflect the same picture of cycle $_{1}$ with slight increase in OG\% in GY/P and the other correlated traits, and in the same direction either under stress or normal irrigation environments (Table 6 and Fig.1). However, single trait selection for GY/P failed to improve GY/P under normal irrigation environment. The best method in improving GY/P, NS/P was index 5 which incorporated the traits GY/P, 
$100 \mathrm{GW}$ and NG/S. Index 1,2 and 3 which incorporated DH showed insignificant differences with the earlier parent in DH.

Table 3. Phenotypic (PCV) and genotypic (GCV) coefficients of variability in cycle 3 in the $\mathrm{F}_{5}$ generation under normal irrigation evaluation.

\begin{tabular}{|c|c|c|c|c|c|c|c|c|c|c|}
\hline Sele. for & Sel. cite & Item & DH & $\begin{array}{c}\mathrm{PH} \\
(\mathrm{cm})\end{array}$ & $\begin{array}{l}\text { SL } \\
(\mathrm{cm})\end{array}$ & NS & $\begin{array}{c}\text { GY/P } \\
(\mathrm{g})\end{array}$ & $\begin{array}{c}\text { MSW } \\
(\mathrm{g})\end{array}$ & $\begin{array}{c}\text { 100-GW } \\
\text { (g) }\end{array}$ & $\mathrm{NG} / \mathrm{S}$ \\
\hline \multirow{4}{*}{ GY/P } & \multirow{2}{*}{$S$} & GCV\% & 2.39 & 8.37 & 12.37 & 26.33 & 22.25 & NS & 8.92 & NS \\
\hline & & PCV\% & 2.49 & 8.56 & 12.55 & 26.54 & 23.33 & $\mathrm{NS}$ & 8.99 & NS \\
\hline & \multirow{2}{*}{$\mathrm{N}$} & GCV\% & 4.37 & 8.16 & 12.02 & 8.83 & 18.87 & NS & 15.72 & 12.13 \\
\hline & & PCV\% & 4.40 & 8.27 & 12.10 & 10.98 & 18.67 & NS & 15.74 & 14.10 \\
\hline \multirow{4}{*}{ Index 1} & \multirow{2}{*}{$\mathrm{S}$} & GCV\% & 7.83 & 9.93 & 13.23 & 9.83 & 19.96 & 34.35 & 9.92 & 33.18 \\
\hline & & PCV\% & 7.84 & 10.08 & 13.51 & 9.85 & 20.91 & 34.44 & 10.21 & 33.31 \\
\hline & \multirow{2}{*}{$\mathrm{N}$} & GCV\% & 8.02 & 7.51 & 16.03 & 8.70 & 10.20 & 21.62 & 12.02 & 27.60 \\
\hline & & PCV\% & 8.03 & 7.71 & 16.49 & 8.72 & 10.68 & 21.72 & 12.04 & 27.65 \\
\hline \multirow{4}{*}{ Index 2} & \multirow{2}{*}{ S } & GCV\% & 10.88 & 8.52 & 8.92 & 17.45 & 12.40 & 32.89 & 5.21 & 29.52 \\
\hline & & PCV\% & 10.90 & 8.63 & 9.25 & 18.40 & 13.59 & 32.98 & 5.67 & 29.75 \\
\hline & \multirow{2}{*}{$\mathrm{N}$} & GCV\% & 2.61 & 6.94 & 16.46 & 16.51 & 23.75 & 28.13 & 10.76 & 23.32 \\
\hline & & PCV\% & 2.93 & 7.04 & 16.80 & 18.67 & 24.94 & 28.28 & 10.81 & 23.57 \\
\hline \multirow{4}{*}{ Index 3} & \multirow{2}{*}{$\mathrm{S}$} & GCV\% & 4.96 & 10.07 & 15.01 & 9.47 & 27.02 & 31.59 & 13.25 & 22.20 \\
\hline & & PCV\% & 5.00 & 10.32 & 15.46 & 10.50 & 27.56 & 31.69 & 13.56 & 22.50 \\
\hline & & GCV\% & 4.81 & 8.81 & 17.41 & 12.21 & 14.55 & 17.19 & 10.35 & 25.15 \\
\hline & & PCV\% & 5.08 & 8.97 & 17.76 & 12.58 & 15.63 & 17.47 & 10.76 & 25.44 \\
\hline \multirow{4}{*}{ Index 4} & \multirow{2}{*}{$\mathrm{S}$} & GCV\% & 4.13 & 7.74 & 11.50 & 14.97 & 16.81 & 23.30 & 5.42 & 21.63 \\
\hline & & PCV\% & 4.17 & 7.89 & 11.92 & 15.64 & 17.85 & 23.55 & 5.98 & 22.13 \\
\hline & & GCV\% & 4.80 & 7.51 & 12.47 & 9.49 & 18.40 & 22.60 & 9.71 & 32.45 \\
\hline & & PCV\% & 4.83 & 7.53 & 13.00 & 10.18 & 20.33 & 23.73 & 9.93 & 33.38 \\
\hline \multirow{4}{*}{ Index 5} & \multirow{2}{*}{ S } & GCV\% & 4.33 & 8.38 & 11.53 & 12.30 & 14.99 & 24.34 & 8.92 & 28.48 \\
\hline & & PCV\% & 4.34 & 8.55 & 11.91 & 12.56 & 16.53 & 24.40 & 8.96 & 28.58 \\
\hline & & GCV\% & 4.27 & 5.88 & 8.31 & 10.07 & 20.43 & 25.49 & 13.01 & 30.80 \\
\hline & & PCV\% & 4.30 & 5.92 & 8.83 & 10.27 & 21.40 & 25.55 & 13.06 & 30.98 \\
\hline
\end{tabular}

Sele. for $=$ Selection for, Sele. Cite $=$ Selection site, $\mathrm{NS}=$ insignificant genotypes mean squares, $\mathrm{S}=$ drought stress, $\mathrm{N}=$ normal irrigation. 
Selection under normal irrigation gave higher mean and $\mathrm{OG} \%$ as expected compared to selection under drought stress. Ismail et al (1996) noted genetic observed gain in GY/P of $7.92 \%$ from the better parent in 3 cycles of selection. Mahdy et al (1996) reported $12.67 \%$ of the better parent in GY/P after 3 cycles of selection.
Hamam (2008) Improved GY/P by 15.18 and $22.12 \%$ in two populations after 2 cycles of selection. Mahdy et al (2012) after three cycles of selection for GY/P noted OG of 20.16 and $10.97 \%$ of the better parent for drought stress and normal

Table 4. Heritability in narrow sense $\left(\mathrm{b} \mathrm{F}_{5} / \mathrm{F}_{4}\right)$ for the traits under selection pressure.

\begin{tabular}{|c|c|c|c|c|c|c|c|c|c|}
\hline \multirow{2}{*}{ Sel. for } & Sel. site & DH & $\begin{array}{c}\text { PH } \\
(\mathrm{cm})\end{array}$ & $\begin{array}{c}\text { SL } \\
(\mathrm{cm})\end{array}$ & $\mathrm{NS} / \mathrm{P}$ & $\begin{array}{c}\text { GY/P } \\
(\mathrm{g})\end{array}$ & $\begin{array}{c}\text { MSW } \\
(\mathrm{g})\end{array}$ & $\begin{array}{c}100 \mathrm{GW} \\
(\mathrm{g})\end{array}$ & NG/S \\
\hline \multirow{2}{*}{$\mathrm{GY} / \mathrm{P}$} & $\mathrm{S}$ & & & & & 0.1977 & & & \\
\cline { 2 - 10 } & $\mathrm{N}$ & & & & & 0.2577 & & & \\
\hline \multirow{2}{*}{ Index 1 } & $\mathrm{S}$ & 0.4019 & & 0.2227 & 0.3310 & 0.2277 & 0.2616 & 0.3239 & 0.2359 \\
\cline { 2 - 10 } & $\mathrm{N}$ & 0.4009 & & 0.3045 & 0.1231 & 0.1555 & 0.2121 & 0.2249 & 0.1922 \\
\hline \multirow{2}{*}{ Index 2 } & $\mathrm{S}$ & 0.3689 & & & & 0.2888 & & 0.3246 & 0.1812 \\
\cline { 2 - 10 } Index 3 & $\mathrm{N}$ & 0.1645 & & & & 0.1904 & & 0.1912 & 0.2180 \\
\cline { 2 - 10 } & $\mathrm{N}$ & 0.3206 & & 0.2590 & & 0.2424 & & 0.2594 & 0.2057 \\
\hline \multirow{2}{*}{ Index 4 } & $\mathrm{S}$ & & & 0.2837 & & 0.1929 & & 0.2065 & 0.2405 \\
\cline { 2 - 10 } & $\mathrm{N}$ & & & 0.2348 & & 0.0707 & & 0.1850 & 0.1637 \\
\hline \multirow{2}{*}{ Index 5 } & $\mathrm{S}$ & & & & & 0.2067 & & 0.2541 & 0.1471 \\
\cline { 2 - 10 } & $\mathrm{N}$ & & & & & 0.1614 & & 0.2021 & 0.1795 \\
\hline
\end{tabular}

Sele. for $=$ Selection for, Sele . Cite $=$ Selection site, $\mathrm{S}=$ drought stress, $\mathrm{N}=$ normal irrigation .

irrigated selections evaluated under drought stress, and 16.58 and $11 \%$ for drought stress and normal irrigated selections evaluated under normal irrigation. Fellahi et al (2018) Improved GY by $22.83 \%$ through 2 cycles of desired gain index.

\section{Cycle3 selection "F5-generation"}

Cycle $_{3}$ selections either under drought stress or under normal irrigation were evaluated under both environments to identify the proper environment for selection.

\section{Evaluation under drought stress}

The observed genetic gain in GY/P after three cycles of selection in the stress group ranged from $17.98 \%$ for direct selection for GY/P to $23.15 \%$ for index 5 (Table 7 and Fig.1). The OG $\%$ increased from index 1 to index 5 , and all indices were better in improving GY/ $P$ than direct selection for GY/P. The same trend of OG was noticed for normal irrigation group. Direct selection for $G Y / P$ was significantly $(P \leq 0.01)$ increased days to heading either for stress or normal irrigation groups. However, index 1,2 and 3 which involved $\mathrm{DH}$ gave significant $(\mathrm{P} \leq 0.01)$ favorable decrease in days to heading. The $\mathrm{OG}$ in $\mathrm{NS} / \mathrm{P}$ was positive and significant $(\mathrm{P} \leq 0.01)$ for all methods of selection, and selection indices were better in improving NS/P than selection for GY/P. Negative significant 
Table 5. Means, observed (OG\%) and correlated genetic gains in percentage from the better parent in the $\mathrm{F}_{3}$-generation (cycle 1 ) under drought stress $(\mathrm{S})$ and normal irrigation $(\mathrm{N})$.

\begin{tabular}{|c|c|c|c|c|c|c|c|c|c|c|}
\hline $\begin{array}{l}\text { Sel. } \\
\text { for }\end{array}$ & $\begin{array}{l}\text { Sel. } \\
\text { Site }\end{array}$ & Item & $\mathrm{DH}$ & $\begin{array}{l}\mathrm{PH} \\
(\mathrm{cm})\end{array}$ & $\begin{array}{l}\text { SL } \\
(\mathrm{cm})\end{array}$ & $\mathrm{NS} / \mathrm{P}$ & $\begin{array}{c}\text { GY/P } \\
(\mathrm{g})\end{array}$ & $\begin{array}{c}\text { WMS } \\
(\mathrm{g})\end{array}$ & $\begin{array}{c}100 \mathrm{GW} \\
(\mathrm{g})\end{array}$ & $\mathrm{NG} / \mathrm{S}$ \\
\hline \multirow{4}{*}{ GY/P } & \multirow[t]{2}{*}{$S$} & Mean & 79.00 & 80.00 & 12.50 & 7.50 & 14.90 & 2.42 & 4.24 & 68.77 \\
\hline & & $\mathrm{OG} \%$ & $12.06 * *$ & 2.13 & $-22.84 * *$ & $7.14 *$ & $7.97^{*}$ & $-20.20 * *$ & $-15.20 * *$ & $6.10^{*}$ \\
\hline & \multirow[t]{2}{*}{$\mathrm{N}$} & Mean & 82.50 & 82.50 & 12.50 & 12.80 & 17.49 & 3.37 & 4.40 & 68.89 \\
\hline & & OG\% & $14.58 * *$ & 3.13 & $-20.10 * *$ & $16.36 * *$ & -3.37 & $-10.36 * *$ & $-20.00 * *$ & $6.30 *$ \\
\hline \multirow{4}{*}{$\begin{array}{c}\text { Index } \\
1\end{array}$} & \multirow[t]{2}{*}{$\mathrm{S}$} & Mean & 74.00 & 81.00 & 15.55 & 7.55 & 14.92 & 2.28 & 4.30 & 68.77 \\
\hline & & OG\% & 4.96 & 3.41 & -4.00 & 7.90 & $8.10^{* *}$ & $-25.00 * *$ & $-14.10 * *$ & $6.10 *$ \\
\hline & \multirow[t]{2}{*}{$\mathrm{N}$} & Mean & 75.20 & 83.00 & 13.50 & 12.02 & 19.93 & 2.85 & 4.78 & 69.02 \\
\hline & & OG\% & 4.44 & $3.88^{*}$ & $-18.20 * *$ & $9.30 * *$ & $10.10 * *$ & $-24.20 * *$ & $-13.10 * *$ & $6.50 * *$ \\
\hline \multirow{4}{*}{$\begin{array}{c}\text { Index } \\
2\end{array}$} & \multirow[t]{2}{*}{ 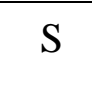 } & Mean & 73.46 & 79.00 & 13.00 & 7.79 & 15.21 & 2.37 & 4.15 & 70.13 \\
\hline & & OG\% & 4.20 & 0.86 & $-19.75 * *$ & $11.30 * *$ & $10.20 * *$ & $-22.10 * *$ & $-17.00 * *$ & $8.20 * *$ \\
\hline & \multirow{2}{*}{$\mathrm{N}$} & Mean & 75.67 & 81.00 & 13.50 & 12.16 & 20.31 & 2.95 & 4.68 & 70.96 \\
\hline & & OG\% & $5.10^{*}$ & 1.38 & $-18.18 * *$ & $10.50 * *$ & $12.20 * *$ & $-21.40 * *$ & $-14.90 * *$ & $9.50 * * *$ \\
\hline \multirow{4}{*}{$\begin{array}{c}\text { Index } \\
3\end{array}$} & \multirow[t]{2}{*}{$S$} & Mean & 73.00 & 82.00 & 15.37 & 7.74 & 15.22 & 2.36 & 4.39 & 71.62 \\
\hline & & OG\% & 3.55 & $4.69 *$ & $-5.10 *$ & $10.50 * *$ & $10.30 * *$ & $-22.30 * *$ & $-12.20 * *$ & $10.50 * *$ \\
\hline & \multirow[t]{2}{*}{$\mathrm{N}$} & Mean & 75.58 & 84.00 & 13.61 & 12.14 & 20.72 & 3.18 & 4.88 & 71.93 \\
\hline & & GA\% & $4.97 *$ & $5.13 * *$ & $-17.50 * *$ & $10.40 * *$ & $14.50 * *$ & $15.39 * *$ & $-11.20 * *$ & $11.00 * *$ \\
\hline \multirow{4}{*}{$\begin{array}{c}\text { Index } \\
4\end{array}$} & \multirow[t]{2}{*}{ 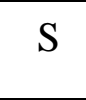 } & Mean & 80.00 & 82.00 & 15.63 & 7.74 & 15.47 & 2.39 & 4.45 & 72.27 \\
\hline & & OG\% & $13.48 * *$ & $4.69 *$ & -3.50 & $10.60 * *$ & $12.10 * *$ & $-21.20 * *$ & $-11.10 * *$ & $11.50 * *$ \\
\hline & \multirow{2}{*}{$\mathrm{N}$} & Mean & 81.12 & 84.00 & 13.70 & 12.57 & 21.01 & 3.71 & 4.98 & 72.91 \\
\hline & & OG\% & $12.67 * *$ & $5.13 * *$ & $-17.00 * *$ & $14.30 * *$ & $16.10 * *$ & -1.27 & $-9.50 * *$ & $12.50 * *$ \\
\hline \multirow{4}{*}{$\begin{array}{c}\text { Index } \\
5\end{array}$} & & Mean & 79.00 & 82.00 & 14.00 & 7.95 & 16.05 & 2.49 & 4.48 & 73.63 \\
\hline & & OG\% & $12.06 * *$ & $4.69 *$ & $-13.58 * *$ & $13.50 * *$ & $16.30 * *$ & $-18.10 * *$ & $-10.50 * *$ & $13.60 * *$ \\
\hline & \multirow[t]{2}{*}{$\mathrm{N}$} & Mean & 80.65 & 85.00 & 13.51 & 12.78 & 21.48 & 3.68 & 5.05 & 74.85 \\
\hline & & OG\% & $12.01 * *$ & $6.38 * *$ & $-18.10 * *$ & $16.20 * *$ & $18.67 * *$ & -2.10 & $-8.20 * *$ & $15.50 * *$ \\
\hline G 164 & \multirow[t]{2}{*}{$\mathrm{S}$} & Mean & 86.23 & 78.33 & 10.47 & 7.00 & 13.80 & 2.62 & 4.20 & 64.23 \\
\hline Sids 4 & & Mean & 70.50 & 70.59 & 16.20 & 5.05 & 12.91 & 3.04 & 5.00 & 64.81 \\
\hline G 164 & \multirow[t]{2}{*}{$\mathrm{N}$} & Mean & 90.69 & 79.90 & 10.84 & 11.00 & 18.10 & 2.77 & 4.60 & 64.80 \\
\hline Sids 4 & & Mean & 72.00 & 76.92 & 16.50 & 6.43 & 15.46 & 3.76 & 5.50 & 57.84 \\
\hline
\end{tabular}

Sele. for $=$ Selection for, Sele. Cite $=$ Selection site and $*$, ** Significant at 0.05 and 0.01 level of probability, respectively.

$(\mathrm{P} \leq 0.01)^{`} \mathrm{OG}$ in $\mathrm{SL}$ was observed for all methods of selection and both of stress and normal irrigation groups this could be due to the long spike of the better parent Sids4, but mean spike length in all methods of selection was equal or longer than G164 (the lower parents). It could be concluded that selection in these materials under stress was better than under normal irrigation in improving GY/P, when evaluation was done under drought stress and selection index was better than single trait selection.

\section{Evaluation under normal irrigation}

The observer genetic gain in GY/P of the stress group (Table 8 and Fig. 1) ranged from $27.9 \%$ for index 1 to $34.4 \%$ for index 5 . The best index in improving GY/P was index 5 followed by index 4 , index $_{3}$, direct selection for $\mathrm{GY} / \mathrm{P}$, index 2 


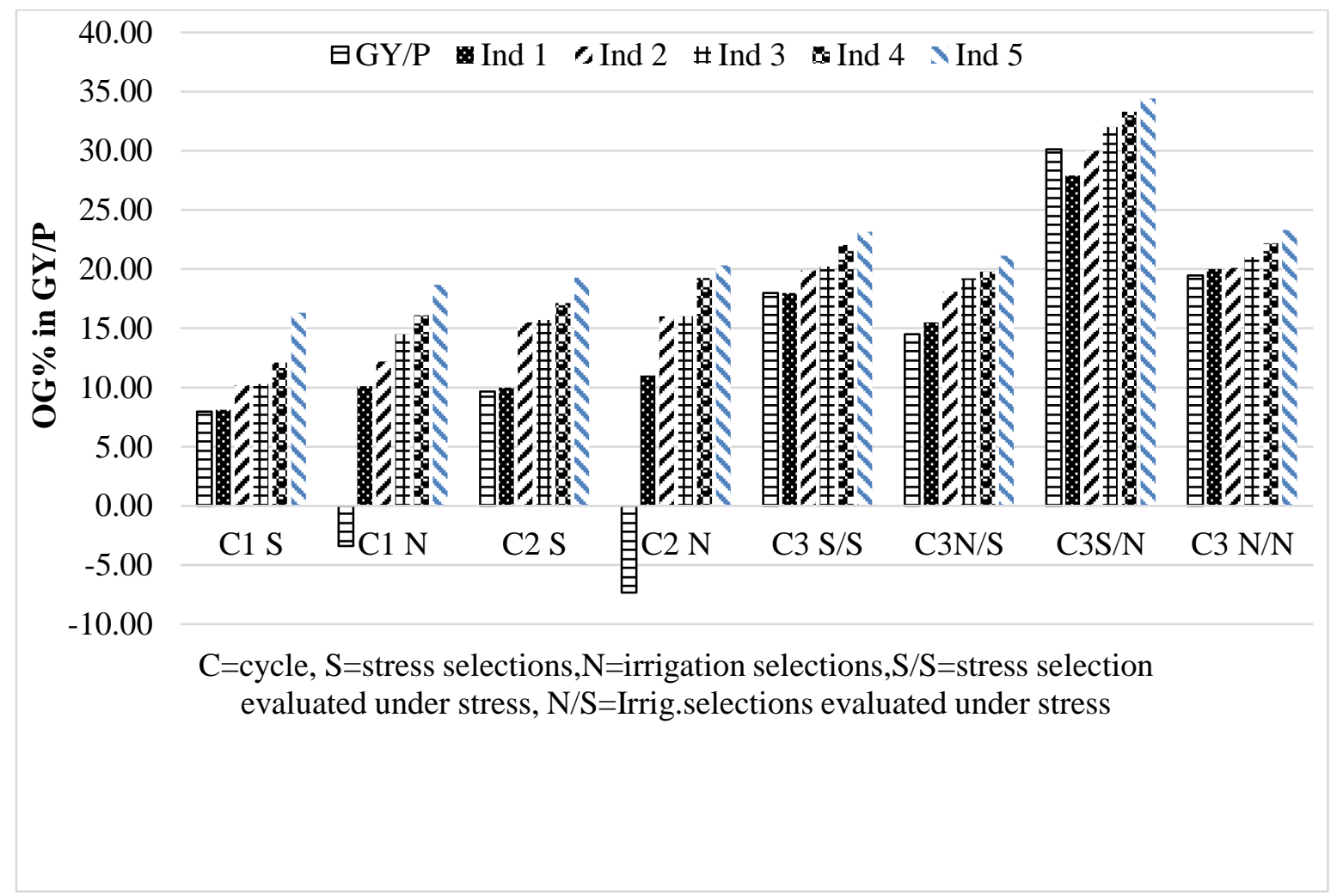

Figure 1. Observed genetic gain in $\mathrm{GY} / \mathrm{P}(\mathrm{OG} \%)$ in percentage from the better parent in the three cycles under drought stress $(\mathrm{S})$ and normal irrigation $(\mathrm{N})$

and index $x_{1}$. However, the observed genetic gain in GY/P of the normal irrigation Group ranged from $19.47 \%$ for single trait selection for $G Y / P$ to $23.3 \%$ for index 5 . All the indices of the normal irrigation group are better than single trait selection for GY/P after 3 cycles of selection. It could be concluded that selection index was better in improving grain yield than single trait selection for GY/P either selection practiced under drought stress or normal irrigation environment. Furthermore, selection under drought stress (antagonistic selection) in this material was better than selection under normal irrigation (synergistic selection) in improving GY/P either selection evaluated under drought stress or under normal irrigation. Falconer (1990) defined "synergistic selection" as selection upward in a good environment or downwards in a bad, and "antagonistic selection as selection upwards in a bad environment or downwards in a good. Selection index 5 which involved GY/P, $100 \mathrm{GW}$ and NG/S was the best index improving GY/P. These results confirmed with result of Jinks and Conolly (1973) and Falconer (1990). Ali (2011) and Mahdy $(2012,2017)$ reached the same conclusion.
The OG in NS/P was positive and significant $(\mathrm{p}<0.01)$ in all selection methods and was in the same trend of the OG of GY/P. Otherwise, the $\mathrm{OG}$ in SL was negative and significant $(\mathrm{P}<0.01)$. This could be due to the long spike of the better parent (Sids4), but the mean of SL was in all cases longer than the lower parent (G164). Respect to $\mathrm{DH}$, selection for GY/P, index4 and index 5 showed positive and significant $(\mathrm{P}<0.01)$ observed genetic gain, however their means of days to heading were earlier than the later parent G164. Index ${ }_{1}, 2$ and 3 which involved DH gave significant $(\mathrm{P}<0.01)$ negative favorable observed gain in $\mathrm{DH}$, and normal irrigation group (antagonistic selection) was better than the drought stress group (synergistic selection) either evaluation was done under drought stress or normal irrigation environment, which conformed Jinks and Conolly (1973) rule and Falconer (1990). Mahdy and Elfarash (2018) reached the same conclusion. 
Table 6. Means, observed (OG\%) and correlated genetic gains in percentage from the better parent in the $\mathrm{F}_{4}$-generation (cycle 2 ) under drought stress (S) and normal irrigation(N).

\begin{tabular}{|c|c|c|c|c|c|c|c|c|c|c|}
\hline \multirow{2}{*}{ Sel.for } & \multirow{2}{*}{ Sel. site } & \multicolumn{9}{|c|}{ Studied traits } \\
\hline & & Item & $\mathrm{DH}$ & $\mathrm{PH}(\mathrm{cm})$ & $\mathrm{SL}(\mathrm{cm})$ & $\mathrm{NS} / \mathrm{P}$ & GY/P (g) & WMS (g) & $100 \mathrm{GW}(\mathrm{g})$ & NG/S \\
\hline \multirow{4}{*}{ GY/P } & \multirow{2}{*}{$\mathrm{S}$} & Mean & 77.97 & 76.72 & 12.78 & 8.61 & 14.55 & 1.45 & 4.24 & 55.10 \\
\hline & & $\mathrm{OG} \%$ & $9.30 * *$ & -2.06 & $-21.73 * *$ & 7.67 & $9.65 *$ & $-19.44 * *$ & $-15.11 * *$ & $7.24 *$ \\
\hline & \multirow{2}{*}{$\mathrm{N}$} & Mean & 81.25 & 83.58 & 12.78 & 13.30 & 17.49 & 1.60 & 4.31 & 57.00 \\
\hline & & $\mathrm{OG} \%$ & $12.85 * *$ & $4.48 * *$ & $-18.40 * *$ & $20.91 * *$ & $-7.32 *$ & $-32.33 * *$ & $-18.15 * *$ & $6.84 *$ \\
\hline \multirow{4}{*}{ Index 1} & \multirow[t]{2}{*}{$\mathrm{S}$} & Mean & 73.41 & 73.65 & 11.37 & 7.75 & 15.40 & 1.47 & 4.31 & 55.10 \\
\hline & & $\mathrm{OG} \%$ & 2.92 & $-5.98 * *$ & $-27.88 * *$ & $11.78 * *$ & $10.00 * *$ & $-26.13 * *$ & $-13.80 * *$ & $7.24 *$ \\
\hline & \multirow[t]{2}{*}{$\mathrm{N}$} & Mean & 74.00 & 79.05 & 11.81 & 11.85 & 20.95 & 1.29 & 4.45 & 59.80 \\
\hline & & $\mathrm{OG} \%$ & $2.78 * *$ & $-1.19 * *$ & $-27.68 * *$ & $12.86^{*}$ & $11.02 * *$ & $-45.44 * *$ & $-15.56 * *$ & $12.62 * *$ \\
\hline \multirow{4}{*}{ Index 2} & \multirow[t]{2}{*}{$\mathrm{S}$} & Mean & 71.00 & 75.35 & 11.32 & 7.80 & 16.17 & 1.60 & 4.17 & 57.00 \\
\hline & & $\mathrm{OG} \%$ & -0.46 & -3.81 & $-28.17 * *$ & $12.50 *$ & $15.50 * *$ & $-19.60 * *$ & $-16.60 * *$ & $10.94 * *$ \\
\hline & \multirow{2}{*}{$\mathrm{N}$} & Mean & 72.00 & 77.83 & 11.88 & 11.90 & 21.89 & 1.93 & 4.48 & 60.10 \\
\hline & & $\mathrm{OG} \%$ & 0.00 & $-2.71 * *$ & $-27.25 * *$ & $13.33 * *$ & $16.00 * *$ & $-18.37 * *$ & $-14.99 * *$ & $13.18 *$ \\
\hline \multirow{4}{*}{ Index 3} & \multirow[t]{2}{*}{$\mathrm{S}$} & Mean & 74.53 & 73.70 & 11.38 & 7.88 & 16.20 & 1.45 & 4.41 & 58.00 \\
\hline & & $\mathrm{OG} \%$ & $4.49 *$ & $-5.91 * *$ & $-27.79 * *$ & $13.65 * *$ & $15.71 * *$ & $-27.14 * *$ & $-11.90 * *$ & $12.88 *$ \\
\hline & \multirow[t]{2}{*}{$\mathrm{N}$} & Mean & 75.00 & 78.08 & 11.82 & 12.00 & 21.90 & 1.52 & 4.41 & 59.30 \\
\hline & & $\mathrm{OG} \%$ & $4.17 *$ & $-2.40 * *$ & $-27.62 * *$ & $14.29 * *$ & $16.06 * *$ & $-35.71 * *$ & $-16.32 * *$ & $11.68 * *$ \\
\hline \multirow{4}{*}{ Index 4} & \multirow[t]{2}{*}{$\mathrm{S}$} & Mean & 77.13 & 75.50 & 12.10 & 7.90 & 16.40 & 1.57 & 4.49 & 58.50 \\
\hline & & $\mathrm{OG} \%$ & $8.13 * *$ & -3.62 & $-23.22 * *$ & $13.94 *$ & $17.14 * *$ & $-21.11 * *$ & $-10.20 * *$ & $13.86^{*}$ \\
\hline & \multirow[t]{2}{*}{$\mathrm{N}$} & Mean & 79.55 & 80.53 & 13.15 & 12.10 & 22.50 & 1.81 & 4.75 & 61.10 \\
\hline & & $\mathrm{OG} \%$ & $10.49 * *$ & 0.66 & $-19.47 * *$ & $15.24 *$ & $19.24 * *$ & $-23.45^{* *}$ & $-9.87 * *$ & $15.07 *$ \\
\hline \multirow{4}{*}{ Index 5} & \multirow[t]{2}{*}{$\mathrm{S}$} & Mean & 78.00 & 73.67 & 11.77 & 8.10 & 16.70 & 1.66 & 4.52 & 60.00 \\
\hline & & $\mathrm{OG} \%$ & $9.35 * *$ & $-5.95 *$ & $-25.32 * *$ & $16.83^{* *}$ & $19.29 * *$ & $-16.58 *$ & $-9.60 * *$ & $16.78 * *$ \\
\hline & \multirow{2}{*}{$\mathrm{N}$} & Mean & 79.00 & 79.42 & 12.68 & 12.20 & 22.70 & 1.78 & 4.69 & 62.00 \\
\hline & & $\mathrm{OG} \%$ & $9.72 * *$ & -0.73 & $-22.33 * *$ & $16.19 *$ & $20.30 * *$ & $-24.80 * *$ & $-10.93 * *$ & $16.76^{* *}$ \\
\hline Giza 164 & \multirow[t]{2}{*}{$\mathrm{S}$} & Mean & 80.00 & 78.33 & 10.00 & 6.93 & 14.00 & 1.80 & 4.00 & 51.38 \\
\hline Sids 4 & & Mean & 71.33 & 66.67 & 15.76 & 5.23 & 12.33 & 1.99 & 5.00 & 47.29 \\
\hline Giza 164 & \multirow[t]{2}{*}{$\mathrm{N}$} & Mean & 86.00 & 80.00 & 11.33 & 10.50 & 18.87 & 2.04 & 4.28 & 53.10 \\
\hline Sids 4 & & Mean & 72.00 & 70.00 & 16.33 & 7.53 & 15.00 & 2.36 & 5.27 & 37.73 \\
\hline
\end{tabular}

Sele. for $=$ Selection for, Sele. Cite $=$ Selection site and $* * *$ Significant at 0.05 and 0.01 level of probability, respectively. 
Table 7. Means, observed and correlated genetic gains (OG\%) in percentage from the better parent for the different indices in the $\mathrm{F}_{5-}$ generation under drought stress evaluation.

\begin{tabular}{|c|c|c|c|c|c|c|c|c|c|c|}
\hline Sel. & Sel. & \multicolumn{9}{|c|}{ Studied traits } \\
\hline \multirow{4}{*}{ GY/P } & \multirow{2}{*}{$\mathrm{S}$} & Mean & 90.73 & 83.80 & 11.27 & 7.80 & 10.50 & 3.17 & 4.30 & 77.00 \\
\hline & & OG\% & $5.81 * *$ & $-11.28 * *$ & $-28.84 * *$ & $9.86 * *$ & $17.98 * *$ & -4.90 & $-6.61 * *$ & 3.17 \\
\hline & \multirow{2}{*}{$\mathrm{N}$} & Mean & 95.20 & 89.00 & 11.57 & 7.60 & 10.19 & 3.00 & 4.25 & 70.00 \\
\hline & & $\mathrm{OG} \%$ & $11.02 * *$ & $-5.77 * *$ & $-26.95 * *$ & $7.04 * *$ & $14.49 * *$ & $-10.00 * *$ & $-7.57 * *$ & $-6.21 * *$ \\
\hline \multirow{4}{*}{ Index 1} & \multirow[t]{2}{*}{$\mathrm{S}$} & Mean & 85.00 & 79.83 & 12.10 & 8.17 & 10.50 & 3.16 & 4.61 & 70.42 \\
\hline & & $\mathrm{OG} \%$ & $-0.87 * *$ & $-15.48 * *$ & $-23.58 * *$ & $15.07 * *$ & $17.98 * *$ & $-5.20 *$ & 0.22 & -5.64 \\
\hline & \multirow[t]{2}{*}{$\mathrm{N}$} & Mean & 81.48 & 82.50 & 11.00 & 7.97 & 10.28 & 2.46 & 4.29 & 57.32 \\
\hline & & $\mathrm{OG} \%$ & $-4.98 * *$ & $-12.66 * *$ & $-30.53 * *$ & $12.25 * *$ & $15.51 * *$ & $-26.20 * *$ & $-6.74 * *$ & $-23.20 * *$ \\
\hline \multirow{4}{*}{ Index 2} & \multirow[t]{2}{*}{$\mathrm{S}$} & Mean & 85.00 & 84.67 & 12.00 & 8.50 & 10.67 & 3.12 & 4.54 & 75.00 \\
\hline & & $\mathrm{OG} \%$ & -0.87 & $-10.36 * *$ & $-24.21 * *$ & $19.72 * *$ & $19.89 * *$ & $-6.40 * *$ & -1.30 & 0.49 \\
\hline & \multirow[t]{2}{*}{$\mathrm{N}$} & Mean & 82.00 & 80.97 & 11.10 & 8.03 & 10.51 & 2.83 & 4.10 & 70.00 \\
\hline & & OG\% & $-4.37 * *$ & $-14.28 * *$ & $-29.89 * *$ & $13.10 * *$ & $18.10 * *$ & $-15.10 * *$ & $-10.87 * *$ & $-6.21 * *$ \\
\hline \multirow{4}{*}{ Index 3} & \multirow[t]{2}{*}{$\mathrm{S}$} & Mean & 84.00 & 78.33 & 12.00 & 8.50 & 10.70 & 3.33 & 4.70 & 78.00 \\
\hline & & $\mathrm{OG} \%$ & $-2.04 * *$ & $-17.07 * *$ & $-24.21 * *$ & $19.72 * *$ & $20.22 * *$ & -0.10 & 2.17 & 4.51 \\
\hline & \multirow[t]{2}{*}{$\mathrm{N}$} & Mean & 83.00 & 84.20 & 11.47 & 7.90 & 10.61 & 2.41 & 4.60 & 75.00 \\
\hline & & $\mathrm{OG} \%$ & $-3.21 * *$ & $-10.86 * *$ & $-27.56 * *$ & $11.27 * *$ & $19.21 * *$ & $-27.70 * *$ & 0.00 & 0.49 \\
\hline \multirow{4}{*}{ Index 4} & \multirow[t]{2}{*}{$\mathrm{S}$} & Mean & 90.00 & 88.17 & 13.27 & 8.50 & 10.86 & 3.04 & 4.93 & 80.00 \\
\hline & & $\mathrm{OG} \%$ & $4.96 * *$ & $-6.65 * *$ & $-16.19 * *$ & $19.72 * *$ & $22.02 * *$ & $-8.80 * *$ & $7.17 * *$ & $7.19 * *$ \\
\hline & \multirow[t]{2}{*}{$\mathrm{N}$} & Mean & 89.30 & 82.90 & 12.43 & 8.30 & 10.66 & 2.80 & 4.43 & 79.00 \\
\hline & & $\mathrm{OG} \%$ & $4.14 * *$ & $-12.23 * *$ & $-21.49 * *$ & $16.90 * *$ & $19.80 * *$ & $-16.00 * *$ & $-3.70 *$ & $5.85 *$ \\
\hline \multirow{4}{*}{ Index 5} & \multirow[t]{2}{*}{$\mathrm{S}$} & Mean & 90.87 & 83.00 & 12.57 & 8.50 & 10.96 & 2.93 & 4.90 & 81.00 \\
\hline & & OG\% & $5.97 * *$ & $-12.13 * *$ & $-20.61 * *$ & $19.72 * *$ & $23.15 * *$ & $-12.10 * *$ & $6.52 *$ & $8.53 * *$ \\
\hline & \multirow{2}{*}{$\mathrm{N}$} & Mean & 90.07 & 84.67 & 12.37 & 8.40 & 10.78 & 2.90 & 4.70 & 80.00 \\
\hline & & $\mathrm{OG} \%$ & $5.04 * *$ & $-10.36 * *$ & $-21.87 * *$ & $18.31 * *$ & $21.12 * *$ & $-13.00 * *$ & 2.17 & $7.19 * *$ \\
\hline Giza 164 & \multirow[t]{2}{*}{$\mathrm{S}$} & Mean & 93.50 & 94.45 & 11.00 & 7.10 & 8.90 & 3.06 & 4.10 & 74.63 \\
\hline Sids 4 & & Mean & 85.75 & 75.00 & 15.83 & 5.10 & 8.20 & 3.33 & 4.60 & 72.46 \\
\hline
\end{tabular}

Sele. for $=$ Selection for, Sele. Cite $=$ Selection site and $* * *$ Significant at 0.05 and 0.01 level of probability, respectively, $\mathrm{S}=$ drought stress and $\mathrm{N}$ $=$ normal irrigation. 
Table 8. Means, observed and correlated genetic gains (OG\%) in percentage from the better parent for the different indices in the F5-generation under normal irrigation evaluation

\begin{tabular}{|c|c|c|c|c|c|c|c|c|c|c|}
\hline \multirow{2}{*}{$\begin{array}{l}\text { Sel. } \\
\text { for }\end{array}$} & \multirow{2}{*}{$\begin{array}{l}\text { Sel. } \\
\text { site }\end{array}$} & \multicolumn{9}{|c|}{ Studied traits } \\
\hline & & Item & $\mathrm{DH}$ & $\mathrm{PH} \mathrm{cm}$ & $\mathrm{SL} \mathrm{cm}$ & $\mathrm{NS} / \mathrm{P}$ & GY/P g & MSW G & $100 \mathrm{GW} g$ & $\mathrm{NG} / \mathrm{S}$ \\
\hline \multirow{4}{*}{ GY/P } & \multirow[t]{2}{*}{$\mathrm{S}$} & Mean & 91.63 & 87.00 & 11.60 & 10.91 & 16.27 & 3.00 & 4.67 & 75.00 \\
\hline & & $\mathrm{OG} \%$ & $2.96 * *$ & $-10.00 * *$ & $-25.16 * *$ & $22.61 * *$ & $30.13 * *$ & $-22.15 * *$ & $-13.44 * *$ & 0.49 \\
\hline & \multirow[t]{2}{*}{$\mathrm{N}$} & Mean & 93.83 & 86.83 & 11.60 & 9.55 & 14.93 & 2.70 & 4.46 & 77.00 \\
\hline & & $\mathrm{OG} \%$ & $5.43 * *$ & $-10.17 * *$ & $-25.16 * *$ & $7.36 * *$ & $19.47 * *$ & -29.93 & $-17.50 * *$ & 3.17 \\
\hline \multirow{4}{*}{ Index 1} & \multirow{2}{*}{$\mathrm{S}$} & Mean & 87.00 & 87.50 & 11.77 & 10.69 & 15.99 & 3.07 & 4.85 & 78.00 \\
\hline & & $\mathrm{OG} \%$ & $-2.25 * *$ & $-9.48 * *$ & $-24.06 * *$ & $20.10 * *$ & $27.90 * *$ & $-20.46 * *$ & $-10.19 * *$ & 4.51 \\
\hline & \multirow{2}{*}{$\mathrm{N}$} & Mean & 85.00 & 82.83 & 12.27 & 10.25 & 15.00 & 2.87 & 4.81 & 75.00 \\
\hline & & $\mathrm{OG} \%$ & $-4.49 * *$ & $-14.31 * *$ & $-20.84 * *$ & $15.20 * *$ & $20.00 * *$ & $-25.52 * *$ & $-10.93 * *$ & 0.49 \\
\hline \multirow{4}{*}{ Index 2} & \multirow{2}{*}{$\mathrm{S}$} & Mean & 86.00 & 85.33 & 11.70 & 10.35 & 16.25 & 3.74 & 4.89 & 93.82 \\
\hline & & $\mathrm{OG} \%$ & $-3.37 * *$ & $-11.73 * *$ & $-24.52 * *$ & $16.29 * *$ & $30.00 * *$ & -2.94 & $-9.44 * *$ & $33.75 * *$ \\
\hline & \multirow[t]{2}{*}{$\mathrm{N}$} & Mean & 84.00 & 86.30 & 12.42 & 10.5 & 15.01 & 3.25 & 4.85 & 82.33 \\
\hline & & $\mathrm{OG} \%$ & $-5.62 * *$ & $-10.72 * *$ & $-19.87 * *$ & $17.98 * *$ & $20.10 * *$ & $-15.66 * *$ & $-10.19 * *$ & $10.31 * *$ \\
\hline \multirow{4}{*}{ Index 3} & \multirow{2}{*}{$\mathrm{S}$} & Mean & 85.00 & 85.50 & 11.96 & 10.69 & 16.50 & 3.12 & 4.40 & 85.50 \\
\hline & & $\mathrm{OG} \%$ & $-4.49 * *$ & $-11.55 * *$ & $-22.84 * *$ & $20.11 * *$ & $32.00 * *$ & $-19.03 * *$ & $-18.52 * *$ & $21.88 * *$ \\
\hline & \multirow[t]{2}{*}{$\mathrm{N}$} & Mean & 82.00 & 84.17 & 12.23 & 10.60 & 15.13 & 3.27 & 4.70 & 75.00 \\
\hline & & $\mathrm{OG} \%$ & $-7.87 * *$ & $-12.93 * *$ & $-21.10 * *$ & $19.10 * *$ & $21.00 * *$ & $-15.14 * *$ & $-12.96 * *$ & 0.49 \\
\hline \multirow{4}{*}{ Index 4} & \multirow[t]{2}{*}{$\mathrm{S}$} & Mean & 92.33 & 86.50 & 13.13 & 10.94 & 16.66 & 3.95 & 4.88 & 95.00 \\
\hline & & $\mathrm{OG} \%$ & $3.74 * *$ & $-10.52 * *$ & $-15.29 * *$ & $22.90 * *$ & $33.28 * *$ & 2.51 & $-9.63 * *$ & $35.43 * *$ \\
\hline & \multirow[t]{2}{*}{$\mathrm{N}$} & Mean & 92.00 & 86.67 & 13.20 & 10.78 & 15.28 & 3.38 & 4.70 & 80.28 \\
\hline & & $\mathrm{OG} \%$ & $3.37 * *$ & $-10.34 * *$ & $-14.84 * *$ & $21.10 * *$ & $22.20 * *$ & $-12.28 * *$ & $-12.96 * *$ & $7.56^{*}$ \\
\hline \multirow{4}{*}{ Index 5} & \multirow[t]{2}{*}{$\mathrm{S}$} & Mean & 92.90 & 86.73 & 13.53 & 11.08 & 16.80 & 4.49 & 4.90 & 98.00 \\
\hline & & $\mathrm{OG} \%$ & $4.38 * *$ & $-10.28 * *$ & $-12.71 * *$ & $24.48 * *$ & $34.40 * *$ & $16.52 * *$ & $-9.26 * *$ & $39.70 * *$ \\
\hline & \multirow[t]{2}{*}{$\mathrm{N}$} & Mean & 91.77 & 86.47 & 13.80 & 10.69 & 15.41 & 3.11 & 4.80 & 81.00 \\
\hline & & $\mathrm{OG} \%$ & $3.11 * *$ & $-10.55 * *$ & $-10.97 * *$ & $20.10 * *$ & $23.30 * *$ & $-19.29 * *$ & $-11.11 * *$ & $8.53 * *$ \\
\hline G 164 & \multirow[t]{2}{*}{$\mathrm{N}$} & Mean & 98.00 & 96.67 & 10.55 & 8.90 & 12.50 & 3.16 & 4.50 & 74.63 \\
\hline Sids 4 & & Mean & 89.00 & 81.67 & 15.50 & 6.20 & 11.28 & 3.85 & 5.40 & 72.46 \\
\hline
\end{tabular}

Sele. for $=$ Selection for, Sele. Cite $=$ Selection site and $* * *$ Significant at 0.05 and 0.01 level of probability, respectively, $\mathrm{S}=$ drought stress and $\mathrm{N}=$ normal irrigation. 


\section{References}

Ahmed, T.A. (2006) 'Efficiency of late and early selection for grain yield under different selection criteria and DNA marker polymorphism in wheat (Triticum aestivum L)', Assiut J. of Agric. Sci., 37, pp. 1-16.

Ali, M.A. (2011) 'Pedigree selection for grain yield in spring wheat (Triticum aestivum L.) under drought stress conditions', Asian $J$. Crop Sci., 3, pp. 158-168.

Bhatt, G. M. (1980) 'Early generation selection for yield in wheat', J. Aust. Inst. Agric. Sci., 46, pp. 14-22.

Borghi, B., Accerbi, M., and Corbellini, M. (1998) 'Response to early generation selection for grain yield and harvest index in bread wheat (T. aestivum L.)', Plant Breed. 117, pp. 13-18.

Burton, G.W. (1952) 'Quantitative inheritance in grasses', $\sigma^{\text {th }}$ Int. Grassland Cong. Pennsylvania state, Proc., 1, pp. 277-283.

Cargnin. A., de Souza, M. A., Machado, C. G., and Pimentel, A. J. B. (2007) 'Genetic gain prediction for wheat with different selection criteria' Crop Breed. Appl. Biot., 7, pp. 334339.

Collins,R. P., Abberton, M. T., MichaelsonYeates, T.P.T., and Rhodes, I. (1997) 'Response to divergent selection for stolon characters in white clover (Trifolium repens)' J. Agric. Sci. 129, pp. 279-285.

El-Karamity, Salem, A.E.M.A., Tammam, A.M., and Mobarek, M.Y.G. (2007) 'Efficiency of some breeding methodologies on some bread wheat populations under new valley conditions' Ph. D. Thesis, El-Minia Univ., Egypt.

F.A.O. (2017) 'Food and Agriculture Organization of United Nations', Statistics Division.

Falconer, D.S. (1990) 'Selection in different environments: effects on environmental sensitivity (reaction norm) and mean performance', Genet. Res. Camb., 56, pp. 5770.

Fellahi, Z. E, Hannachi, A., and Bouzerzour, H. (2018) 'Analysis of direct and indirect selection and indices in bread wheat (Triticum aestivum L.) segregating progeny', Inter. J. of Argon., 2018, pp. 1-11.
Ferdous, M.F., Shamsuddin, A.K.M., Hasna, D., and Bhuiyan, M.M.R. (2010) 'Study on relationship and selection index for yield and yield contributing characters in spring wheat', J. Bangladesh Agric. Univ., 8(2), pp. 191-194.

Gebre-Mariam, H., and Larter, E.N., (1996) 'Genetic response to index selection for grain yield, kernel weight and per cent protein in four wheat crosses', Plant Breed., 115, pp. 459-464.

Ghaed-Rahimi, L., Heidari, B., and Dadkhodaie, A. (2017) 'Construction and efficiency of selection indices in wheat (Triticum aestivum 1.) under drought stress and wellirrigated conditions', Plant Breed. Biotech., 5(2), pp. 78-87.

Hamam, K.A. (2008) 'Pedigree selection in $F_{3}$ and $\mathrm{F}_{4}$ generations for grain yield of durum wheat', Assiut J. of Agric. Sci., 39(1), pp. 111.

Hanson, W.D. (1991) 'Root characteristics associated with divergent selection for seedling aluminum tolerance in soybean', Crop Sci. 31, pp. 125-129.

Hazel, L.N. (1943) 'The genetic basis for constructing selection indexes', Genetics, 28, pp. 576-490.

Ismail, A.A. (1995) 'Pedigree selection for grain yield, grain weight and earliness in two segregating populations of spring wheat', Assiut J. of Agric. Sci., 24(4), pp. 59-72.

Ismail, A.A. (2001) 'Identification of selection traits for yield improvement of bread wheat using path analysis', Assiut J. of Agric. Sci., 32, pp. 63-84.

Ismail, A.A., Mahdy, E.E., and Kheiralla, K.A. (1996) 'The efficiency of selection in F3 and F5 -generations in spring wheat', Assiut J. of Agric. Sci., 27, pp. 3-16.

Jinks, J.L., and Connolly, V. (1973) 'Selection for specific and general response to environmental differences', Heredity, 30, pp. 33-40.

Khan, I., Khalil, I.H., and Nasir-ud-Din (2007) 'Genetic parameters for yield traits in wheat under irrigated and rainfed environments', Sarhad J. Agric., 23, pp. 973-979.

Mahdy, E.E., Ismail, A.A., and Kheiralla, K.A. (1996) 'The relative merits of selection index and pedigree selection in improving grain 
yield of spring wheat', Assiut J. of Agric. Sci., 27, pp. 17-33.

Mahdy, E.E, El-Karamity, A.E., Mokadem, S.A., and Fouad, H.M. (2012) 'Selection for grain yield and its components in two segregating populations of bread wheat, Triticum aestivum L.', Minia Inter. Conf. Agric. Irrig. Nile Basin Countr., El-Minia, Egypt.

Mahdy, E.E. (1988) 'The efficiency of some selection procedures in wheat, Triticum aestivum L.', Cer. Res. Com., 16, pp. 175181.

Mahdy, E.E., El-Karamity, A.E., Mokadem, S.A., Abd-Elmawgood, A.L., and Foad, H.M. (2015) 'Selection for grain yield in bread wheat under normal irrigation and drought stress conditions', J. Plant Prod. Mansoura Univ., 6(4), pp. 547-562.

Mahdy, Rasha, E. (2012) 'Response to selection for earliness and yield in bread wheat under normal and drought conditions', Ph.D. Thesis, Agron. Dept. Fac. Agric. Assiut Univ., Egypt.

Mahdy, Rasha, E. (2017) 'Efficacy of selection for grain yield in the $\mathrm{F}_{2}$ and $\mathrm{F}_{4}$ generations in bread wheat under irrigation and drought conditions', Egypt. J. Plant Breed., 21(4), pp. 825-842.

Mahdy, Rasha, E., and Elfarash, A.E. (2018) 'selection for days to heading under normal irrigation and drought stress conditions with monitoring taelf3 gene expression in bread wheat', Egypt. J. Plant Breed., 22(1), pp. 825-842.

Nass, H. G. (1987) 'Selection for grain yield of spring wheat utilizing seed size and other selection criteria', Can. J. Plant Sci., 67, pp. 605-610.

Pawar, I.S., singh, I., and Singh, S. (1990) 'Traditional versus simplified pedigree selection in wheat', Haryana Agric. Univ. J. Res., 20, pp. 134-138.

Pesek, J., and Baker, R.J. (1970) 'An application of index selection to the improvement of self-pollinated species', Can. J. Plant Sci., 50, pp. 267-276.

Pesek', J. and Baker, R.J. (1969) 'Desired improvement in relation to selection indices', Can. J. Pl. Sci., 49, pp. 803-804.

Sip, V., and Skorpik, M. (1985) 'Evaluation of selection criteria in early hybrid generations of spring wheat', Z. Pflanzenzüchtg, 94, pp. 321-331.

Smith, H.F. (1936) 'A discriminant function of plant selection', Ann. Eugenics, 7, pp. 240250.

Smith, J.D., and Kinman, M.L. (1965) 'The use of parent-offspring regression as an estimator of heritability', Crop Sci., 5(6), pp. 595-596.

Steel, R.G.D. and Torrie, J.H. (1980) 'Principle and Procedures of Statistics' A Biometrical Approach $2^{\text {nd }}$ Ed., McGraw-Hill Book Company, New York, U.S.A.

Talebi, R., Fayaz, F., and Naji, A.M. (2009) 'Effective selection criteria for assessing drought stress tolerance in durum wheat (Triticum durum Desf)', Gen. Appl. Plant Physiol., 35, pp. 64-74.

Walker, T.T. (1960) 'The use of a selection index technique in the analysis of progeny row data', Emp. Cott. Rev., 37, pp. 81-107.

Whan, B. R., Rathjen, A.J., and Knight, R. (1981) 'The relation between wheat lines derived from the $F_{2}, F_{3}, F_{4}$ and $F_{5}$ generations for grain yield and harvest index', Euphytica, 30, pp. 419-430.

Whan, B. R., Knight, R., and Rathjen, A.J. (1982) 'Response to selection for grain yield and harvest index in $F_{2}, F_{3}$ and $F_{4}$ derived linesof two wheat crosses', Euphytica 31, pp. 139-150.

Williams, J.S. (1962) 'The evaluation of a selection index', Biometrics 18, pp. 375-393.

Zakaria, M.M., El-Morshidy, M.A., Khieralla, K.A. and Tammam, A.M. (2008) 'Direct selection for grain yield and correlated response in bread wheat under normal and late sowing dates', Assiut J. of Agric. Sci. 39, pp. 1-16. 